\title{
Changing the Cotton Fiber Temperature
}

\author{
Ruzmetov R.I., Madumarov I.D., Gapparova M.A., Tuychiev T.O
}

\begin{abstract}
Absract: The article investigates the dependence of the temperature of cotton fiber on the time spent on drying-cleaning equipment. The study also investigated the effect of hot air velocities on cotton. According to the study, the increase in hot air temperature for drying from $2.5 \mathrm{~m} / \mathrm{s}$ to $7 \mathrm{~m} / \mathrm{s}$ leads to an increase in the temperature of the fiber to $10 \div 12{ }^{\circ} \mathrm{C}$. It was found that the increase in the temperature of the fiber can be achieved by increasing its velocity without increasing the air temperature.
\end{abstract}

Keywords: Cotton fiber, drying, cleaning, cotton moisture, cotton fiber temperature, drying agent temperature, air velocity.

\section{INTRODUCTION}

Gradual and sustainable development of the cotton industry, introduction of modern equipment in the industry, increase of the level of efficient and rational use of production capacities, production of competitive products on the world cotton market. In this regard, special attention is paid to the improvement of high-efficiency cotton drying equipment and the creation of resource-saving technologies in the global cotton industry. However, the analysis of cotton drying and cleaning equipment used by foreign and local cotton factories shows that today there are no effective solutions to the creation of high-efficiency cotton cleaning technologies. Initial processing of cotton starts with drying, as the quality of cotton products and the efficiency of process equipment depend on the moisture content of the cotton. More than ten thousand types of materials have been dried up in the world, of which cotton is a multicomponent material with a variety of trophophysical properties and is one of the most complex drying facilities. Therefore, the quality of cotton in the drying process, the selection of drying modes of the equipment, the detailed study of the properties of cotton as a drying material and the process of drying equipment [1]. The intensity of the drying process and the moisture performance depends on the initial parameters of the cotton. Convective drying depends on the movement of moisture from the interior of the material to the surface, the heat and moisture exchange between the material and the external environment.

The amount of heat transferred from hot air to cotton is expressed by the following equation [1].

$\mathrm{Q}=\mathrm{KP} \mathrm{P}_{\mathrm{da}} \cdot \mathrm{F}\left(\mathrm{t}_{1}-\mathrm{t}_{2}\right)$

here, heat exchange between the K-drying agent and cotton

Revised Manuscript Received on February 05, 2020.

* Correspondence Author

Ruzmetov R.I*., Tashkent Institute of Textile and Light Industry, Researcher

Madumarov I.D., Tashkent Institute of Textile and Light Industry, Doctor of Technical Sciences.

Gapparova M.A., Tashkent Institute of Textile and Light Industry, candidate of technical sciences.

Tuychiev T.O., Tashkent Institute of Textile and Light Industry, Ph.D.

(C) The Authors. Published by Blue Eyes Intelligence Engineering and Sciences Publication (BEIESP). This is an open access article under the CC BY-NC-ND license (http://creativecommons.org/licenses/by-nc-nd/4.0/) coefficient, $\mathrm{kdj} / \mathrm{m}^{2} \mathrm{hr} *$ grad;

$\mathrm{P}_{\mathrm{da}}$ - hot air volume, $\mathrm{m}^{3} /$ hour;

F- heat-absorbing surface, $\mathrm{m}^{2}$

$\mathrm{t}_{1}-\mathrm{t}_{2}={ }_{\Delta} \mathrm{t}-$ difference between drying agent and cotton temperature, ${ }^{\circ} \mathrm{C}$.

We can see that the amount of heat transferred from the hot air to the cotton depends on the heat transfer coefficient between the drying agent and the cotton, the amount of heat absorbed by the drying surface, and the temperature difference between the hot and the cotton. It is evident that this can be achieved by increasing the heat exchange between the material and the environment to accelerate the drying process, and by increasing the heat transfer coefficient.

In drum dryers, the drying agent acts not only as a heat carrier but also as an agent that absorbs moisture and removes it from the drying chamber.

The amount of moisture evaporating from the surface is calculated using the following equation [1]:

$$
\frac{d W}{d \mathrm{v}}=ß\left(\mathrm{p}_{\mathrm{m}}-\mathrm{p}_{\mathrm{w}}\right) \mathrm{dF}
$$

here, $\frac{d W}{d \mathrm{\tau}}$ - moisture evaporation from the material, $\mathrm{kg} / \mathrm{h}$;

ß- coefficient of evaporation;

F- area of the evaporation surface, $\mathrm{m}^{2}$;

$\mathrm{N} / \mathrm{m}^{2}$

$\mathrm{p}_{\mathrm{w}}$ - Percent pressure of water vapor in hot air,

$\mathrm{N} / \mathrm{m}^{2}$

$\mathrm{p}_{\mathrm{m}}$ - vapor pressure on the material surface

The formula shows that moisture evaporation depends on the surface area of the cotton, which increases the moisture content of the cotton, which increases the moisture content of the surface of the material and the moisture content inside the material. The rate of moisture evaporation on the surface of the material is also influenced by the pressure of the vapor in the environment, and the lower the pore pressure, the faster the moisture evaporation occurs. The reduction of the vapor pressure in the drying agent can be achieved by the supply of a new drying agent that is not used in the drying process.

\section{FORMULATION OF THE PROBLEM.}

Based on the theoretical research, the technology of high-speed drying agent proposed in the process of cotton drying process, the ability of the drying agent to perpendicular to the cotton stream, the high degree of clutter (in the case of lumps and drifts, but not the arrows), always lower than the material vapor pressure and allow air moisture content of $6-8 \mathrm{~g} / \mathrm{kg}$ [2; 3].

Based on the above considerations, the aim was to investigate the effect of hot air temperature and velocity on changes in cotton fiber temperature. The experiments were carried out in cotton varieties S-6524, of the 1st grade variety, with an initial humidity of $9.20 \%$ and $11.05 \%$, and a pollution of $3.20 \%$ and $2.98 \%$.

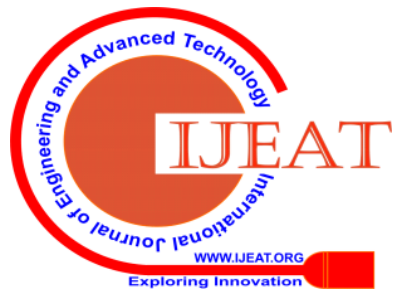




\section{Changing the Cotton Fiber Temperature}

The air velocity required for drying cotton during experiments is $2.5 ; 4.0 ; 5.5$ and $7.0 \mathrm{~m} / \mathrm{s}$ with temperatures $120 ; 140 ; 160$ and $180{ }^{\circ} \mathrm{C}$, drying time was taken at 10,20 , 30 and 40 seconds. State standards O'z DSt 643:2006 and O'z DSt 644:2006 are used to determine the moisture content of cotton dried cotton $[4 ; 5]$.

The first section of the LCM instrument was used to conduct the experiments to remove cotton from the dirt. Depending on the time ratios of the unit, the lid was moved to the Dirty Cleaning Unit in the required seconds, and the cotton was placed in a polyethylene sack and immediately measured using a contact thermometer with an accuracy of $0.01{ }^{\circ} \mathrm{C}$

The SXL-3 ventilator spindle was adjusted to maintain the required air speed. The air velocity was determined by measuring the velocity of air coming out of the inlet of the heat agent transmission tube from the SXL-3 device to the LCM. The size of the inlet section of the heat transfer pipe to the LCM is measured using a crossanemometer that measures the velocity of air coming out of this perimeter to $30 \mathrm{~m} / \mathrm{s}$.

An additional automatic was mounted on the SXL3 to transfer the required air to the LKM, and the capacity of the tubular heat generators was increased. Temperature was determined using a mercury thermometer.

Initial Cotton Pollution Level before Experimentation it is defined on the basis of State standard O'z DSt 592. After setting the required regime, $300 \mathrm{~g}$ of cotton samples were obtained using the method described in the state standard O'z DSt 643 on the scales with a accuracy of $0.01 \mathrm{~g}$. After the sample was supplied to the LKM device, the heat was transferred and the release time was recorded. After the required time, the cap of fine dirt from the cotton was opened and placed in a polythene sack, and immediately the temperature of the cotton fiber was measured on the contact thermometer. Then the moisture content of the cotton was determined on the VXS-M1 using the method described in the State Standard O'z DSt 644. During the experiment weighed the separated impurities, and the efficiency of the sample and device purification was determined. The experiments were conducted in three repetitions to avoid possible errors.

\section{SOLUTION METHOD}

During the drying of cotton the physical and mechanical changes of fiber occur. The amount of these changes depends on the initial moisture content of the cotton, the heating temperature of the cotton and the duration of the drying process. Determining the dependence of these factors on the drying process is important in maintaining the spinning properties of fiber, which is one of the main tasks of the cotton drying process.

The first heat treatment of cotton has been used by mankind since ancient times. This is not reflected in the technological processes of domestic cotton processing. This process is effectively used in US cotton processing technology. Of course, the local cotton gin is heated during the initial processing of cotton. However, heating the cotton is not intended to increase the temperature of the fiber, but to dry it to air humidity. During the drying of cotton, the temperature of the fiber falls to its purification process and does not exceed $25-30{ }^{\circ} \mathrm{C}$. [7] The study showed that the fiber coefficient increases as the temperature of the fiber increases. This increases the permeability of the fiber shock by the drum drum, and the efficiency of cleaning is directly proportional to the shock force's transmission to the fiber. In the study [8] the optimum temperature of the fiber during drying was determined to be $65 \div 70{ }^{\circ} \mathrm{C}$, which mainly investigated the effect of the fiber on appearance.

Scientists of JSC "Pakhtasanoat Scientific Center" and the Tashkent Institute of Textile and Light Industry revealed changes in the quality of the fiber during drying and suggested different modes of drying operation. This study was mainly done on drum-type dryers.

\section{ANALYSIS OF THE RESULTS}

Figure 1-4 shows graphs of the change in cotton fiber temperature dependence of the drying agent velocity.

Figure 1 (a) shows that the moisture content of the cotton is $11.05 \%$, with the air velocity for drying at $2.5 \mathrm{~m} / \mathrm{s}$ and the temperature at $120^{\circ} \mathrm{C}$, the temperature of the cotton fiber after drying the cotton for 10 seconds. (curve 1), cotton the temperature after 20 seconds of drying is $38{ }^{\circ} \mathrm{C}$, the temperature after 30 seconds is $42{ }^{\circ} \mathrm{C}$, and the temperature after 40 seconds is $44{ }^{\circ} \mathrm{C}$.

When the air temperature for cotton drying is $140{ }^{\circ} \mathrm{C}$ (curve 2), the temperature of the cotton fiber reaches $35^{\circ} \mathrm{C}$ in 10 seconds, up to $41{ }^{\circ} \mathrm{C}$ in 20 seconds and $45^{\circ} \mathrm{C}$ in 30 seconds. After drying for 40 seconds, the temperature increases to $48{ }^{\circ} \mathrm{C}$, which is about $18-20^{\circ} \mathrm{C}$. The air temperature is $160{ }^{\circ} \mathrm{C}$ (curve 3); the temperature of the cotton fiber after drying the cotton for 10, 20, 30 and 40 seconds is 38; 44; 49 and $530 \mathrm{C}$, and the temperature at 180 ${ }^{\circ} \mathrm{C}$ is 41 ; 48; Up to 53 and $56{ }^{\circ} \mathrm{C}$. The air temperature for cotton drying is $120^{\circ} \mathrm{C}$, with an increase in the temperature of the dried cotton fiber up to $16-18{ }^{\circ} \mathrm{C}$ for 40 seconds, and the temperature of the cotton fiber by $20-22$, when the temperature increases to 140,160 and $180{ }^{\circ} \mathrm{C}$; Increase in the range of $24-26$ and $27-29^{\circ} \mathrm{C}$ is observed.
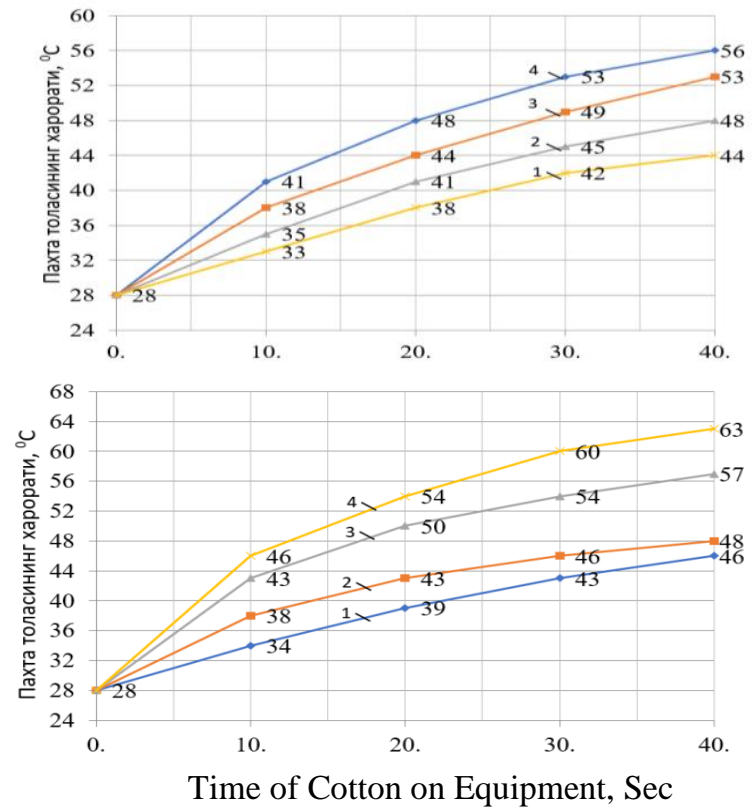

a)

b)

$1,2,3,4-120,140,160,180^{\circ} \mathrm{C}$, respectively

Figure 1. Graph of dependence of changes in the cotton fiber temperature at drying time (humidity a) $11.05 \%$ and $b)-9,20 \%$, air speed $2.5 \mathrm{~m} / \mathrm{s}$ ) 
In Figure 1 (b), the moisture content of the cotton is 9.20\%, with the air temperature for drying at $120{ }^{\circ} \mathrm{C}$ and the temperature of the cotton fiber after drying for 10 seconds (Curve 1), after 20 seconds of drying, the temperature is 39 ${ }^{\circ} \mathrm{C}$, after 30 seconds the temperature is $43{ }^{\circ} \mathrm{C}$, and the temperature after dried for 40 seconds is $46{ }^{\circ} \mathrm{C}$. When the air temperature for cotton drying is $140{ }^{\circ} \mathrm{C}$ (curve 2), the temperature of the cotton fiber is $38^{\circ} \mathrm{C}$ in 10 seconds, $43{ }^{\circ} \mathrm{C}$ after 20 seconds, $46{ }^{\circ} \mathrm{C}$ after 30 seconds and $48^{\circ}$ after 40 seconds. C. are forming. The temperature was $160{ }^{\circ} \mathrm{C}$ (curve 3 ) and the temperature after cotton drying for 10, 20, 30 and 40 seconds was 43; 50; Increase in temperature from 54 to $57^{\circ} \mathrm{C}$, and temperature at $180{ }^{\circ} \mathrm{C}$ is 46 ; 54 ; An increase of 60 and $63{ }^{\circ} \mathrm{C}$ is observed. When the air temperature for cotton drying is $120^{\circ} \mathrm{C}$, the temperature of the fiber is $16-18$ ${ }^{\circ} \mathrm{C}$, and the temperature is $19-21,28-30$ and $34-36{ }^{\circ} \mathrm{C}$ when the air temperature rises to 140,160 and $180{ }^{\circ} \mathrm{C}$ the number of rise temperature of cotton fiber in the process of cotton cleaning recommended temperatures of $45-50{ }^{\circ} \mathrm{C}$ [9], with a 9.2 percent cotton drying rate of $2.5 \mathrm{~m} / \mathrm{s}$ with a temperature of $160{ }^{\circ} \mathrm{C}$ within 15 seconds, the temperature increases to 48 to50 ${ }^{\circ} \mathrm{C}$. Figure 2 (a) shows a time-varying temperature of the dried cotton temperatures at different temperatures at 4.0 $\mathrm{m} / \mathrm{s}$ for air drying with $11.05 \%$ humidity.

The air temperature was $120^{\circ} \mathrm{C}$ after 10 seconds of drying, the temperature of the cotton fiber was $34^{\circ} \mathrm{C}$. The temperature is expected to rise to $140{ }^{\circ} \mathrm{C}$, cotton temperature to $38{ }^{\circ} \mathrm{C}$ in 10 seconds, to $43^{\circ} \mathrm{C}$ in 20 seconds, to $48{ }^{\circ} \mathrm{C}$ in 30 seconds and to $51{ }^{\circ} \mathrm{C}$ after 40 seconds. The air temperature is $160{ }^{\circ} \mathrm{C}$ and the temperature is 40 , respectively, after drying the cotton for $10,20,30$ and 40 seconds; 46; 51 and $55^{\circ} \mathrm{C}$, with temperatures reaching 180 ${ }^{\circ} \mathrm{C}$; 49; Up to 56 and $60{ }^{\circ} \mathrm{C}$. Air temperature was 120,140 , 160 and $180{ }^{\circ} \mathrm{C}$, and the temperature of cotton fiber 19-21, 22-24; Increase of $26-28$ and $31-33^{\circ} \mathrm{C}$ is observed.
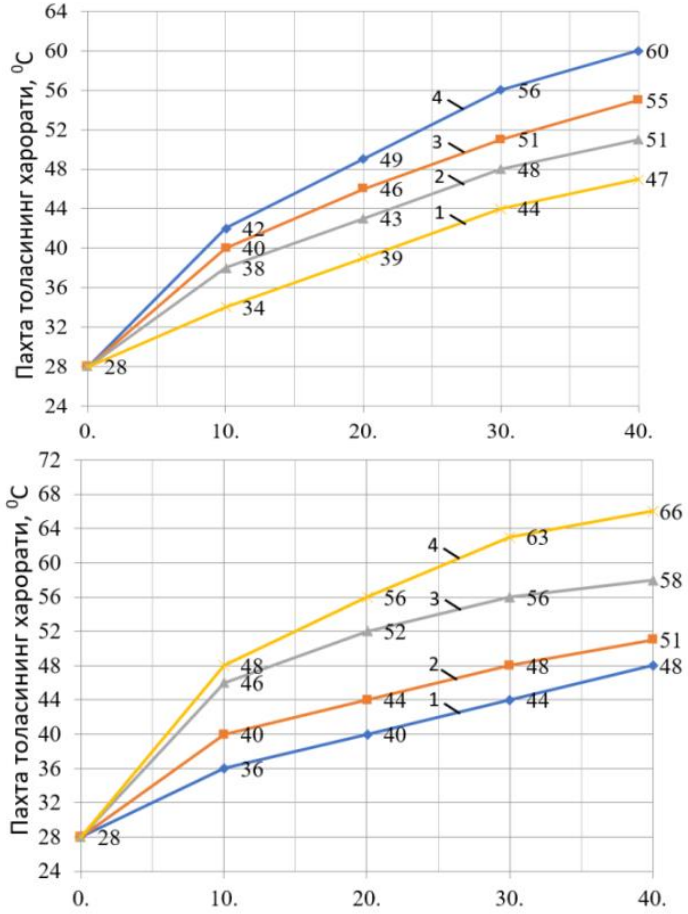

Time of Cotton on Equipment, Sec a)

1, 2, 3, $4-120,140,160,180^{\circ} \mathrm{C}$, respectively

Figure 2. Graph of dependence of changes in the cotton fiber temperature at drying time (humidity a) $11.05 \%$ and b) $-9,20 \%$, air speed $4.0 \mathrm{~m} / \mathrm{s}$ )
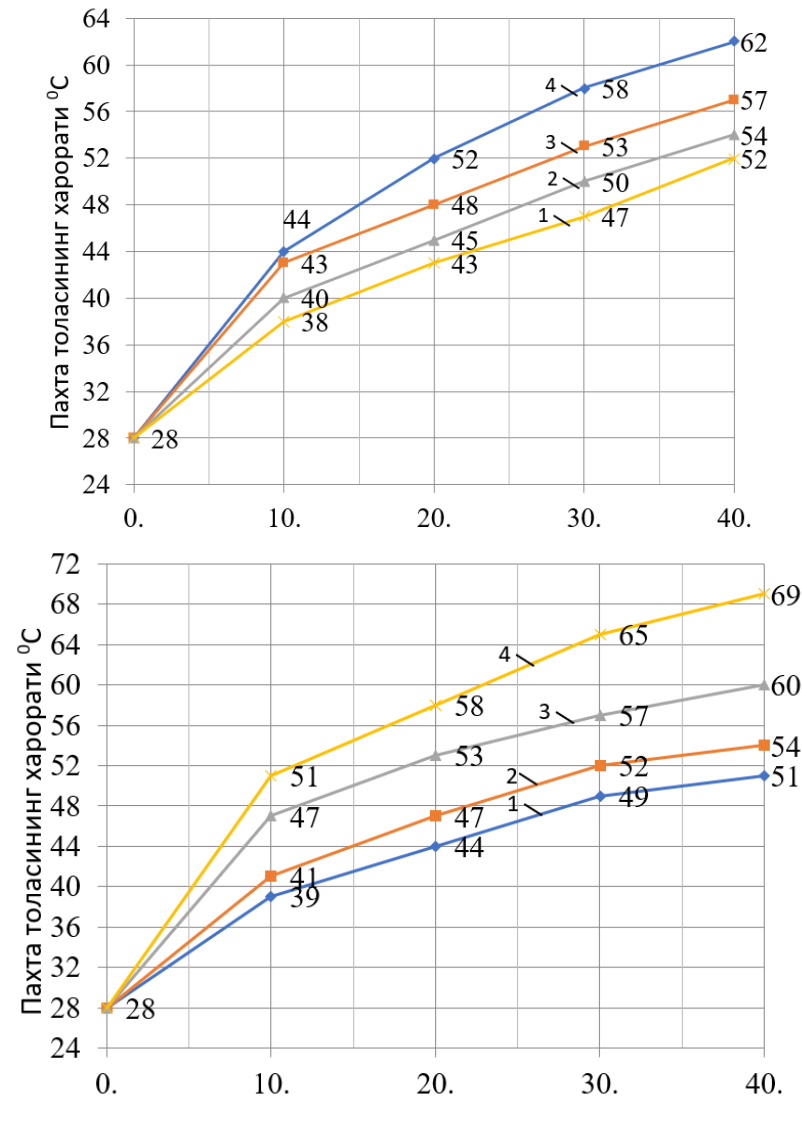

Time of Cotton on Equipment, Sec

a)

b)

$1,2,3,4-120,140,160,180^{\circ} \mathrm{C}$, respectively

Figure 3. Graph of dependence of changes in the cotton fiber temperature at drying time (humidity a) $\mathbf{1 1 . 0 5 \%}$ and $\mathrm{b})-\mathbf{9 , 2 0} \%$, air speed $5.5 \mathrm{~m} / \mathrm{s}$ )

Analyzing the graphs in Figures 3 and 4 show that the temperature of cotton fiber increases with increasing air velocities and temperatures for cotton drying.

As shown in Figure 2 (b), the air temperature is 120 ${ }^{\circ} \mathrm{C}$, its velocity at $4 \mathrm{~m} \mathrm{/} \mathrm{s} \mathrm{and} 10$ seconds drying, the temperature of the cotton fiber is $36^{\circ} \mathrm{C}$, and after 20,30 and 40 seconds the temperature of the cotton fiber is 40,44 and $48^{\circ} \mathrm{C}$. The air temperature for cotton drying is $140{ }^{\circ} \mathrm{C}$ and after 10, 20, 30 and 40 seconds, the temperature rises to 40 , 44, 48 and $51^{\circ} \mathrm{C}$. Likewise, the air temperature for drying is 160 and $180{ }^{\circ} \mathrm{C}$ (curves 3-4) and the temperature of the cotton fiber after drying for $10,20,30$ and 40 seconds is 46 ; 52; 56; 58 and 48; 56; 63; Up to $66^{\circ} \mathrm{C}$.

As shown in the graphs, the temperature of cotton fiber for drying up to $11.05 \%$ with temperature of 120 0C and the speed of $2.5 \mathrm{~m} / \mathrm{s}$, when the cotton fiber temperature increases by $48-500 \mathrm{C}$ for $40 \mathrm{sec}$. It takes 36 seconds to raise the cotton fiber temperature to $48^{\circ} 50^{\circ} \mathrm{C}$.

When the temperature is increased to $5.5-7.0 \mathrm{~m} / \mathrm{s}$ it takes 32 and 25 seconds, respectively, to raise the cotton fiber temperature to 48-50 0C. Air temperature for cotton drying is $1400 \mathrm{C}$, speed 2.5 ; 4.0 ; At 5.5 and $7.0 \mathrm{~m} / \mathrm{s}$, it took 36, 30, 25 and 20 seconds to raise the cotton fiber temperature to $48-50 \mathrm{0C}$, and to $30,28,20$ and 20 , respectively. 15 seconds and 25, 20, 15 and 10 seconds, when the temperature rises to 180 degrees.

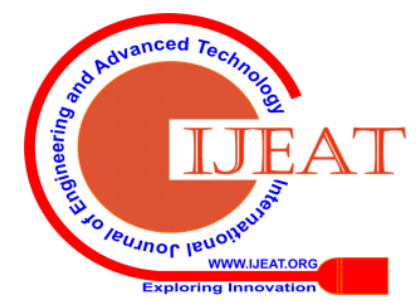




\section{Changing the Cotton Fiber Temperature}
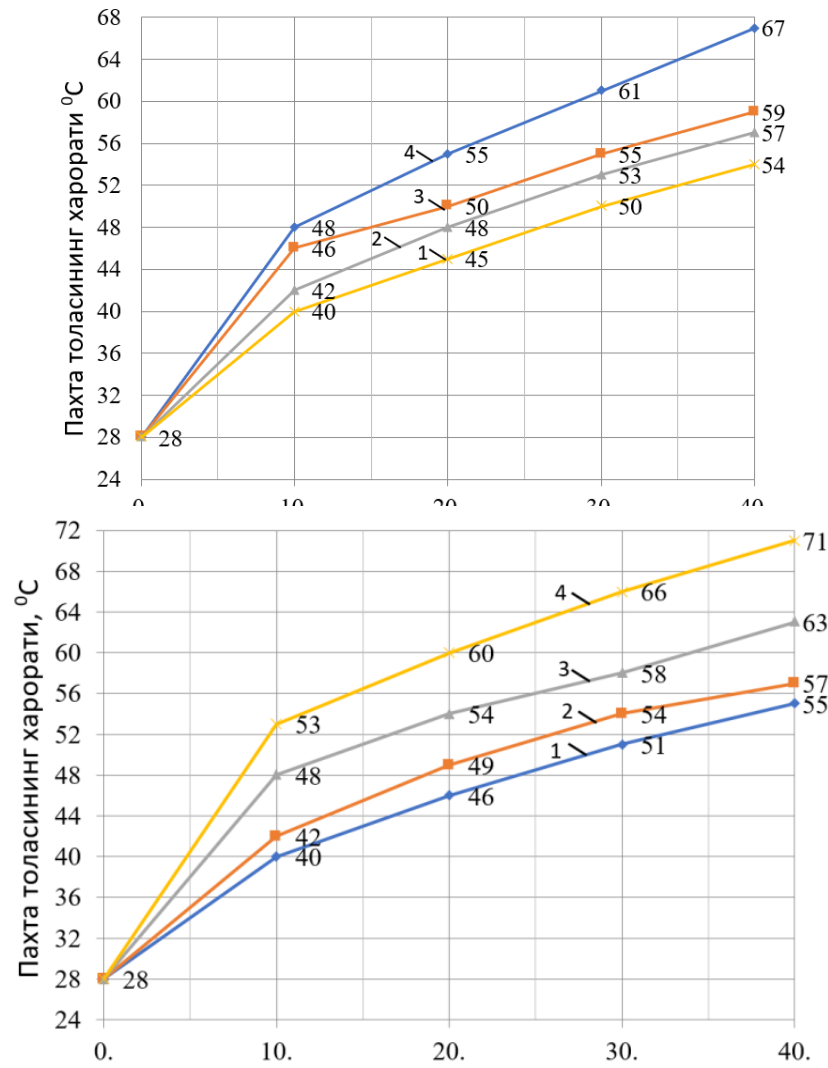

Time of Cotton on Equipment, Sec a)

b)

$1,2,3,4-120,140,160,180^{\circ} \mathrm{C}$, respectively

Figure 4. Graph of dependence of changes in the cotton fiber temperature at drying time (humidity a) $11.05 \%$ and b) $-9,20 \%$, air speed $7.0 \mathrm{~m} / \mathrm{s}$ )

The moisture content of the cotton is $9.2 \%$, the temperature of the hot air $120^{\circ} \mathrm{C}$, with a speed of $2.5 \mathrm{~m} / \mathrm{s}, 38$ seconds increase of cotton fiber temperature $48-50{ }^{\circ} \mathrm{C}$, while the temperature of hot air is 4.0; Increasing to 5.5 and 7.0 $\mathrm{m} / \mathrm{s}$, we see that the temperature of the cotton fiber can rise to $48-50{ }^{\circ} \mathrm{C}$ for 30.28 and 20 seconds, respectively. As well as the rest of the graphs, the rapid increase in the temperature of cotton fiber can be achieved by increasing the temperature and speed of hot air drying.

\section{CONCLUSION}

The study found that the rate of hot air for drying increased from $2.5 \mathrm{~m} / \mathrm{s}$ to $7 \mathrm{~m} / \mathrm{s}$, leading to an increase in the cotton fiber temperature by 10 to $12^{\circ} \mathrm{C}$. As a result, it is proved by the practical experience that increasing the temperature of the fiber, even without increasing the temperature of the hot air, can be achieved by increasing the temperature of the hot air. Considering the fact that the temperature of hot air in the cotton fiber exceeds $55-60^{\circ} \mathrm{C}$ and negative impact on the natural quality of the fiber, it will be possible to obtain a high-quality product by introducing the results of this study into production. It also saves fuel consumption for hot air.

\section{REFERENCES}

1. Parpiev A.A., Akhmatov M.A., Muminov M., Usmankulov A.K. Drying of cotton. Textbook. T .: Chulpon, 2009. - 192 pages.

2. Ruzmetov R.I., Madumarov I.D., Tuychiev T.O., Mardonov B.M. Modeling of heat exchange processes between raw cotton and coolant in a screw drum European science review, Vienna, Prague, 2018, 5-6, -
P.335-338.

3. Madumarov I.D. Tuychiev T.O., Mardonov B.M. Ruzmetov R.I. Movement of the trash inside of fiber material when available elastic force of clutch. Engineering, 10, USA, -P.579-587.

4. State standard O'zDSt 643:2006 «Cotton. Methods of sampling», Uzbek Agency for Standardization, Metrology and Certification, Tashkent, 2006.

5. State standard O'zDSt 644:2006 «Cotton. Methods of Determination of Humidity», Uzbek Agency for Standardization, Metrology and Certification, Tashkent, 2006.

6. Patent UZ № FAP 00328. Cotton drying and cleaning device Madumarov I., Parpiev A., Lugachev A., Ruzmetov R.I. - 2007, -12.

7. Saidov S. Improving the efficiency of drum dryers using two-stage drying of raw cotton. Diss. for the degree of Can. Tashkent. 1989.

8. Sadykov M. Improving the supply and internal devices of a drum dryer for raw cotton. Diss. for the degree of Can. Tashkent. 1984.

9. Madumarov I.D. Increasing the efficiency of the cotton cleaning process based on the optimization and uniformity of the heat and humidity conditions of cotton // Diss. for the degree of Doc. (DSc) T., 2019. 